\title{
Implementasi Sistem Pendukung Keputusan untuk Pemilihan Siswa Berprestasi di Sekolah Menengah Atas dengan Metode AHP dan TOPSIS
}

\author{
Implementation of Decision Support System for Outstanding Students Selection at Senior High School \\ Using AHP and TOPSIS Methods
}

\author{
Adhim Jati Kusuma ${ }^{a}$, Adjie Pramana Putra ${ }^{b}$, Julianto Lemantara ${ }^{c}$ \\ ${ }^{a, b, c}$ Universitas Dinamika, Surabaya, Indonesia \\ email: ${ }^{\mathrm{a}}$ 18410100162@dinamika.ac.id , ${ }^{\mathrm{b}}$ 18410100163@dinamika.ac.id, ${ }^{c}$ julianto@dinamika.ac.id
}

Menerima 19 November 2021, Revisi 24 November 2021, Diterima 14 Desember 2021, Online 15 Desember 2021

\begin{abstract}
ABSTRAK
Karena tingginya tingkat kompetisi antar siswa maupun antar sekolah, maka Sekolah Menengah Atas (SMA) perlu melakukan seleksi siswa berprestasi untuk memunculkan kemauan bersaing antar siswa secara sehat dengan melibatkan berbagai pertimbangan. Adapun pertimbangan kriteria didalamnya yaitu nilai akademik, prestasi non akademik, sikap, perilaku, bakat, riwayat organisasi, dan penilaian ekstrakurikuler berdasarkan kurikulum 2013. Saat ini, banyak SMA melakukan proses penilaian secara manual sehingga membutuhkan waktu 1-2 minggu. Selain itu, proses pemilihan siswa berprestasi untuk kegiatan perlombaan juga masih melibatkan subjektivitas dari beberapa guru saja yang mengindikasikan kurang optimalnya hasil yang didapatkan karena menandakan adanya keberpihakan. Oleh karena itu, dibangunlah aplikasi Sistem Pendukung Keputusan (SPK) pemilihan siswa berprestasi dengan metode Analytical Hierarchy Process (AHP) dan Technique for Order Preference by Similarity to Ideal Solution (TOPSIS) dengan model pengembangan Extreme Programming. Untuk proses pengujian fungsi aplikasi SPK ini dilakukan dengan metode Black-Box serta pengujian tingkat keakurasian menggunakan 104 sampel dan 6 kriteria yang ada dengan membandingkan antara hasil aplikasi dan hasil perhitungan secara manual. Hasil penelitian menunjukkan pengguna SPK ini dapat terbantu untuk menyelesaikan pemilihan siswa berprestasi dengan waktu kurang dari 20 menit. Tingkat keakurasian yang dihasilkan oleh aplikasi ini mencapai $100 \%$.

Kata kunci: Sistem Pendukung Keputusan, AHP, TOPSIS, Berprestasi.
\end{abstract}

\section{ABSTRACT}

Due to the high level of competition between students and between schools, Senior high schools need to select outstanding students to raise a will to compete among students in a healthy manner by involving various considerations. The consideration of the criteria in it are academic values, non-academic achievements, attitudes, behaviors, talents, organizational histories, and extracurricular assessments based on the 2013 curriculum. Currently, many Senior High School carry out the assessment process manually, so it takes 1-2 weeks. In addition, the process of selecting outstanding students for competition activities also still involves the subjectivity of some teachers, which indicates that the results obtained are not optimal because they indicate parttiality. Therefore, a Decision Support System (DSS) was designed for the selection of outstanding students using Analytical Hierarchy Process (AHP) and Technique for Order Preference by Similarity to Ideal Solution (TOPSIS) method with Extreme Programming development model. For the testing process about the function of this DSS application, it was carried out using the Black-Box method. For testing the accuracy level using existing 104 samples and 6 criteria by comparing between the application results and the manual calculation results. The study results showed the DSS users can be helped to complete the outstanding student selection less than 20 minutes. The accuracy level produced by this application reaches $100 \%$.

Keyword: Decision Support System, AHP, TOPSIS, Achiever. 


\section{PENDAHULUAN}

Dalam kaitannya dengan dunia pendidikan, teknologi juga perlu diimplementasikan dengan lebih baik, terutama pada tingkat Sekolah Menengah Atas (SMA) dalam rangka menghasilkan siswa-siswa terbaik didalamnya. Siswa terbaik ini perlu dipilih oleh sekolah melalui pemilihan dan penilaian sesuai dengan standar yang ada. Dalam prosesnya, penentuan siswa berprestasi seharusnya tidak didasarkan atas penilaian akademik saja, namun juga ada aspek/kriteria yang lainnya (Jodi, 2017). Ada beberapa kriteria penilaian yang diperlukan untuk dapat memberikan hasil yang maksimal yaitu melalui 3 aspek domain utama sesuai dengan penilaian hasil belajar pada Kurikulum 2013 yaitu kognitif, afektif, keterampilan. Ketiganya dijabarkan menjadi 6 aspek penilaian yang lebih detail yaitu nilai akademik, prestasi non-Akademik, sikap, perilaku, bakat minat, serta riwayat organisasi (Setiadi, 2016). Adapun proses untuk mengelola kategori tersebut dilakukan oleh pendidik dan satuan pendidik melalui tahapan mengkaji silabus sebagai acuan perencanaan penilaian, pembuatan kisi-kisi instrumen dan penetapan kriteria penilaian, pelaksanaan penilaian dalam proses pembelajaran, menganalisis hasil penilaian dan memberi tindak lanjut atas penilaian yang dilakukan oleh pendidik, serta menyusun laporan hasil penilaian dalam bentuk deskripsi pencapaian kompetensi dan deskripsi sikap (Setiadi, 2016). Contohnya saja aspek perilaku, perilaku ini dapat mengalami perubahan akibat proses belajar (akademik) yang dapat mempengaruhi aspek lainnya yaitu kognitif, sikap, dan juga keterampilan siswa (Ekayani, 2017).

Di sisi lain, pemilihan siswa berprestasi ini pada umumnya masih melibatkan subjektivitas dari guru pengajar ataupun wali kelas serta masih menggunakan perhitungan secara manual. Hal ini dapat menyebabkan tidak akuratnya hasil yang dimunculkan serta lamanya proses seleksi yang bisa memakan waktu 1-2 minggu atau bahkan lebih. Permasalahan-permasalahan itulah yang biasa dijumpai pada banyak SMA saat proses pemilihan siswa berprestasi untuk dikirim ke suatu event atau kegiatan perlombaan. Banyak SMA mengutus siswa berprestasi ke suatu kegiatan perlombaan hanya berdasarkan kriteria tertentu saja dan unsur subjektivitas yang tinggi. Padahal, pemilihan siswa berprestasi sebaiknya dilakukan dengan bijaksana dan tidak boleh dilakukan secara sembarangan (Mulyoningtyas, dkk., 2016). Pemilihan siswa berprestasi harus dilakukan secara objektif dan melibatkan banyak kriteria atau aspek penilaian sehingga menghasilkan keputusan yang tepat guna meningkatkan peluang sekolah dalam meraih prestasi di level yang lebih tinggi, baik provinsi, nasional, maupun internasional.

Maka dari itu perlu adanya penyelesaian permasalahan dengan membuat sistem pendukung keputusan dengan menggunakan metode AHP (Analytical Hierarchy Process) dan TOPSIS (Technique for Order Preference by Similarity to an Ideal Solution). Metode AHP sendiri digunakan untuk memecahkan persoalan yang kompleks dengan menstruktur suatu hierarki kriteria, pihak kepentingan, hasil, dan dengan menarik berbagai pertimbangan guna mengembangkan bobot atau prioritas (Munthafa \& Mubarok, 2017). Sedangkan metode TOPSIS ini digunakan untuk mengidentifikasi solusi dari himpunan alternatif berdasarkan minimalisasi simultan dari jarak titik ideal dan memaksimalkan jarak dari titik terendah (Chamid, 2016). Penelitian ini menggabungkan antara AHP dan TOPSIS dengan tujuan agar didapatkan hasil yang lebih akurat dalam memberikan rekomendasi bagi pengambil keputusan sesuai dengan tujuan dan model pengimplementasian yang dilakukan pada penelitian Fadlan, dkk (2017). Di sisi lain juga AHP memiliki kelebihan berdasar pada matriks perbandingan pasangan dan melakukan analisis konsistensi. Sedangkan TOPSIS dapat menyelesaikan pengambilan keputusan secara praktis, karena konsep yang sederhana dan mudah dipahami, komputasi efisien, serta memiliki kemampuan mengukur kinerja relatif dan alternatif-alternatif keputusan (Chamid \& Murti, 2017). Jadi dapat disimpulkan bahwa metode AHP ini sangat baik untuk menghasilkan bobot kriteria yang konsisten dan metode TOPSIS sangat baik untuk menghasilkan pemeringkatan terhadap alternatif yang dikirim ke suatu event (Lemantara \& Utama, 2009) (Lemantara, Setiawan, \& Aji, 2013)

Dari masalah yang ada, dapat dirumuskan tujuan penelitian yaitu membantu sekolah untuk memilih calon siswa berprestasi sesuai dengan kriteria pertimbangan, termasuk masing-masing bobotnya sehingga menghasilkan pertimbangan yang optimal dan meningkatkan keyakinan sekolah untuk mengikutkan siswa yang dimaksud ke perlombaan siswa berprestasi di tingkat yang lebih tinggi dengan memperbaiki penelitian pada topik pembahasan yang serupa. Perbaikan terhadap penelitian serupa telah diuraikan pada bagian penelitian terdahulu.

\section{KAJIAN PUSTAKA}

\section{Penelitian Terdahulu}

Penelitian sebelumnya dilakukan oleh Nyura dkk (2020) untuk pemilihan siswa berprestasi juga menggunakan metode yang sama, namun memiliki kekurangan dimana setiap nilai harus dikonversi nilai terlebih dahulu sehingga nilai yang dihasilkan ada kemungkinan tidak akurat, jika beberapa alternatif memiliki range nilai yang sama pada tiap kriterianya, dimana setiap range nilai pada tiap alternatif harus dikonversi dahulu ke suatu nilai yang dapat mengakibatkan tingkat keakuratan penilaian berkurang. Ada juga penelitian juga yang diimplementasikan di SMAN 7 Surakarta, dimana kekurangannya adalah tidak ada penggunaan sifat kriteria yang biasanya ada benefit atau cost dengan hanya menggunakan 5 kriteria saja (Rahman, dkk., 2020). 
Berdasarkan dari 2 penelitian sebelumnya yang serupa, ada beberapa poin perbaikan dari jurnal-jurnal tersebut, seperti nilai masing-masing kriteria dimunculkan secara real tanpa adanya konversi, dapat melibatkan atribut untuk masing-masing kriteria (cost dan benefit), dan jumlah kriteria yang dapat ditambah/dikurangi oleh pendidik agar dapat disesuaikan dengan kebutuhan dan aturan kurikulum yang berlaku (kriteria bersifat dinamis).

Ada pula penelitian yang dilakukan oleh (Lesmana \& Nugroho, 2021) untuk pemilihan siswa berprestasi, tetapi hanya menggunakan metode TOPSIS saja. Kekurangan dari penelitian ini terletak pada penentuan bobot kriteria. Dalam metode TOPSIS, bobot kriteria ditentukan secara langsung oleh penilai, tanpa melakukan proses perbandingan tingkat kepentingan antara kriteria sehingga hasil pembobotan hanya menggunakan perkiraan atau intuisi. Selain itu, penentuan bobot kriteria hanya dengan metode TOPSIS ini tidak dilakukan pengujian konsistensi sehingga bobot kriteria belum terjamin konsistensinya dengan tingkat kepentingannya. Di sisi lain, ada juga penelitian yang menggunakan metode AHP saja tanpa digabungkan dengan metode lain, seperti penelitian yang dilakukan oleh (Pangaribuan, Sylvia, \& Hutabarat, 2021). AHP memang bisa digunakan untuk penentuan bobot sekaligus pemeringkatan alternatif. Hanya saja, pemeringkatan dengan metode AHP ini memiliki kelemahan yaitu proses perbandingan antar alternatif yang lebih kompleks/rumit pada setiap kriteria yang digunakan, jika dibandingkan dengan metode TOPSIS. Oleh karena itu, penelitian ini melakukan kombinasi AHP dan TOPSIS untuk memanfaatkan kelebihan dari masing-masing metode.

\section{Algoritma Analytical Hierarchy Process}

Menurut Utama (2017) mengemukakan bahwa, "AHP adalah sebuah konsep untuk pembuatan keputusan berbasis multi kriteria (kriteria yang banyak). Beberapa kriteria yang dibandingkan satu dengan lainnya (tingkat kepentingannya) adalah penekanan utama pada konsep AHP ini". AHP ini digunakan untuk membantu penentuan keputusan yang didalamnya menggabungkan subjektifitas dan data yang nantinya akan dilakukan pembobotan sesuai dengan prioritas yang sudah ditentukan di dalamnya. Skala perbandingan disajikan dalam Tabel 1.

\section{Tabel 1. Intensitas Kepentingan Dalam AHP}

\begin{tabular}{cl}
\hline Intensitas Kepentingan & \multicolumn{1}{c}{ Keterangan } \\
\hline 1 & Kedua elemen mempunyai pengaruh yang sama (sama pentingnya) \\
\hline 3 & $\begin{array}{l}\text { Pengalaman dan penilaian sangat memihak satu elemen dibandingkan dengan pasangannya } \\
\text { (sedikit lebih penting) }\end{array}$ \\
\hline 5 & Elemen yang satu lebih penting daripada yang lainnya \\
\hline 7 & Satu elemen jelas lebih mutlak penting daripada elemen lainnya (lebih penting) \\
\hline 9 & Satu elemen mutlak penting daripada elemen lainnya (mutlak lebih penting) \\
\hline $2,4,6,8$ & $\begin{array}{l}\text { Nilai-nilai antara 2 nilai pertimbangan-pertimbangan yang berdekatan Respirokal kebalikan jika } \\
\text { elemen i memiliki salah satu angka di atas ketika dibandingkan elemen j, maka j memiliki } \\
\text { kebalikannya ketika dibandingkan elemen }\end{array}$ \\
\hline
\end{tabular}

Adapun rangkuman untuk langkah-langkah menghitung AHP menurut Azis dkk (2017) adalah (1) Membuat matriks perbandingan berpasangan dengan menggunakan acuan Tabel 1, (2) Normalisasi keputusan, (3) Menentukan bobot kriteria, (4) Analisis konsistensi.

\section{Algoritma Technique for Order Preference by Similarity to an Ideal Solution}

Technique for Order Preference by Similarity to an Ideal Solution (TOPSIS) digunakan sebagai cara untuk mengasumsikan bahwa setiap kriteria akan dimaksimalkan ataupun diminimalkan. Solusi ideal positif didefinisikan sebagai jumlah dari seluruh nilai terbaik yang dapat dicapai untuk setiap atribut, sedangkan solusi ideal negatif terdiri dari seluruh nilai terburuk yang dicapai untuk setiap atribut, maka asumsi dasar dari TOPSIS adalah ketika solusi ideal positif tidak dapat dicapai (Azis, dkk., 2017), pembuat keputusan akan mencari solusi yang sedekat mungkin dengan solusi ideal positif. TOPSIS memberikan solusi ideal positif yang relatif dan bukan solusi ideal positif yang absolute karena dalam metode TOPSIS klasik, nilai bobot dari setiap kriteria telah diketahui dengan jelas dan ditentukan berdasarkan tingkat kepentingannya menurut pengambil keputusan (Marbun \& Sinaga, 2018). Adapun rangkuman proses perhitungannya menurut Azis dkk (2017) yaitu (1) Membuat matriks keputusan, (2) Membuat matriks keputusan ternormalisasi, (3) Membuat matriks keputusan ternormalisasi terbobot, (4) Menentukan solusi ideal positif dan matriks solusi ideal negatif, (5) Menentukan jarak antara nilai setiap alternatif dengan solusi ideal positif dan negatif, (6) Menentukan nilai preferensi untuk setiap alternatif.

\section{METODE PENELITIAN}

Dalam penelitian ini menggunakan metode Extreme Programming. Metode Extreme Programming sendiri adalah sebuah proses rekayasa perangkat lunak yang cenderung menggunakan pendekatan berorientasi objek dan sasaran dari metode ini adalah tim yang dibentuk dalam skala kecil sampai medium serta metode ini juga 
sesuai dengan adanya requirement yang tidak jelas maupun terjadi perubahan requirement yang sangat cepat (Supriyatna, 2018). Adapun tahapan-tahapan penelitian yang dilakukan dapat dilihat pada Gambar 1.

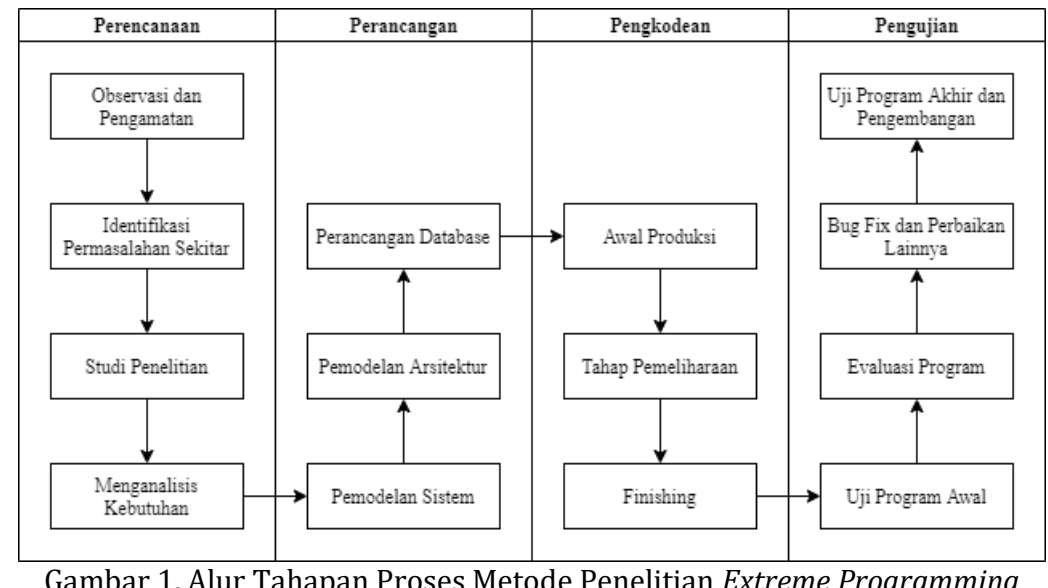

\section{Planning (Perencanaan)}

Tahapan ini dimulai dengan observasi atau pengamatan serta melakukan identifikasi permasalahan yang ada sampai dengan penetapan pembangunan sistem (Carolina \& Supriyatna, 2019). Pada tahap ini, penulis melakukan observasi proses penilaian yang dilakukan oleh sekolah yang berpatokan pada standarisasi kurikulum 2013 yang didapatai memiliki 6 kriteria utama untuk dijadikan poin penilaian (akademik, prestasi non-Akademik, sikap, perilaku, bakat minat, serta riwayat organisasi), kebutuhan fungsional, kebutuhan nonFungsional, serta hasil akhir yang diinginkan. Dalam proses ini ditentukan beberapa permasalahan yaitu proses seleksi/pemilihan siswa berprestasi yang terlalu memakan waktu serta adanya subjektivitas yang terjadi dalam proses itu. Sehingga dalam pembuatan aplikasi web untuk pemilihan siswa berprestasi tingkat SMA dimulai dengan merumuskan kebutuhan sistem secara dasar yang nantinya dilanjutkan dengan menganalisis kebutuhan pengguna yang lain agar sistem yang dibangun sesuai dengan yang diharapkan. Dalam hal ini digambarkan dalam bentuk diagram Input Proses Output (IPO).

Pada tahap ini dilakukan dengan melakukan analisis kebutuhan perangkat lunak terlebih dahulu dengan melakukan beberapa penyesuaian sesuai dengan prosedur perhitungan AHP-TOPSIS dalam deskripsi umum perangkat lunak. Adapun beberapa kebutuhan SPK Pemilihan Siswa Berprestasi ini telah dirangkum di Tabel 2.

Tabel 2. Kebutuhan perangkat lunak SPK Pemilihan Siswa Berprestasi

\begin{tabular}{lll}
\hline \multicolumn{1}{c}{ Jenis Kebutuhan } & & \multicolumn{1}{c}{ Fungsi } \\
\hline Kebutuhan Fungsional & 1. & Fungsi pengolahan data event (kegiatan) \\
& 2. & Fungsi pengolahan kriteria dan bobot kriteria (tingkat kepentingan) \\
& 3. & Fungsi pengolahan data siswa dan nilai siswa \\
& 4. & Fungsi perhitungan untuk penentuan siswa berprestasi dengan AHP TOPSIS \\
& 5. & Fungsi dashboard dan Laporan ranking \\
& 6. & Fungsi pengelolaan data pengguna \\
\hline Kebutuhan Non-Fungsional & 1. & Sistem keamanan data (Hak akses tiap pengguna) \\
\hline
\end{tabular}

Dari tahap penentuan kebutuhan yang sudah dijelaskan pada tabel 2, langkah selanjutnya adalah menentukan kebutuhan data dalam bentuk diagram Input Proses Output (IPO) yang dapat dilihat pada Gambar 2. Dalam diagram IPO pada Gambar 2 tersebut dijelaskan beberapa input yang dibutuhkan untuk setiap proses yang juga akan menghasilkan luaran sesuai dengan yang diharapkan. Untuk aktivitas yang dapat dilakukan oleh pengguna yang ada pada aplikasi SPK Pemilihan Siswa Berprestasi ini dapat dilihat dalam pemodelan sistem berdasarkan akses dan fungsi yang diberikan kepada masing-masing pengguna.

\section{Design (Perancangan)}

Pada tahapan perancangan ini dilakukan pembuatan model sistem yang didasarkan pada hasil analisis kebutuhan yang didapatkan. Dalam pemodelan sistem ini menggunakan beberapa hal didalamnya yaitu Use-Case Diagram, Sequence Diagram dan Class Diagram. Use-Case Diagram sendiri adalah suatu diagram yang menggambarkan interaksi antara sistem dengan lingkungan yang berada di luar sistem, dengan kata lain UseCase ini memvisualisasikan siapa pengguna sistem dan bagaimana user berinteraksi dengan sistem tersebut (Tristianto, 2018). Sequence Diagram adalah sebuah diagram yang digunakan untuk menjelaskan sebuah interaksi yang dapat dilakukan antar objek. Class Diagram adalah bentuk visualisasi dari struktur sistem dengan penggambaran model database. Sedangkan untuk pemodelan basis datanya menggunakan Physical Data Model (PDM) yang didasarkan dengan Class Diagram. 
Pemodelan sistem digambarkan dalam bentuk Use Case Diagram, seperti yang tampak pada Gambar 3. Setelah mengetahui proses aktivitas yang dapat dilakukan oleh masing-masing pengguna serta kebutuhankebutuhan didalamnya, tahap selanjutnya yaitu pembuatan Sequence Diagram untuk masing-masing use case yang ada pada Use Case Diagram. Sequence Diagram ini menggambarkan aksi yang dapat dilakukan oleh aktor untuk menunjukkan interaksi antar objek. Dalam publikasi penelitian ini, sequence Diagram yang digambarkan hanya yang berkaitan dengan proses-proses utama dalam SPK pemilihan siswa berprestasi saja, misalnya sequence diagram untuk menggambarkan proses mengelola kriteria kegiatan, seperti yang tampak pada Gambar 4. Pada Gambar 4 terlihat bahwa aktor berinteraksi dengan banyak hal, seperti halaman dashboard dan halaman kriteria kegiatan, aktor juga terlibat untuk ke controller yaitu kriteria dengan model kriteria kegiatan. Proses 1.1 adalah untuk input kriteria kegiatan sedangkan proses 1.2 adalah untuk menghapus kriteria kegiatan.
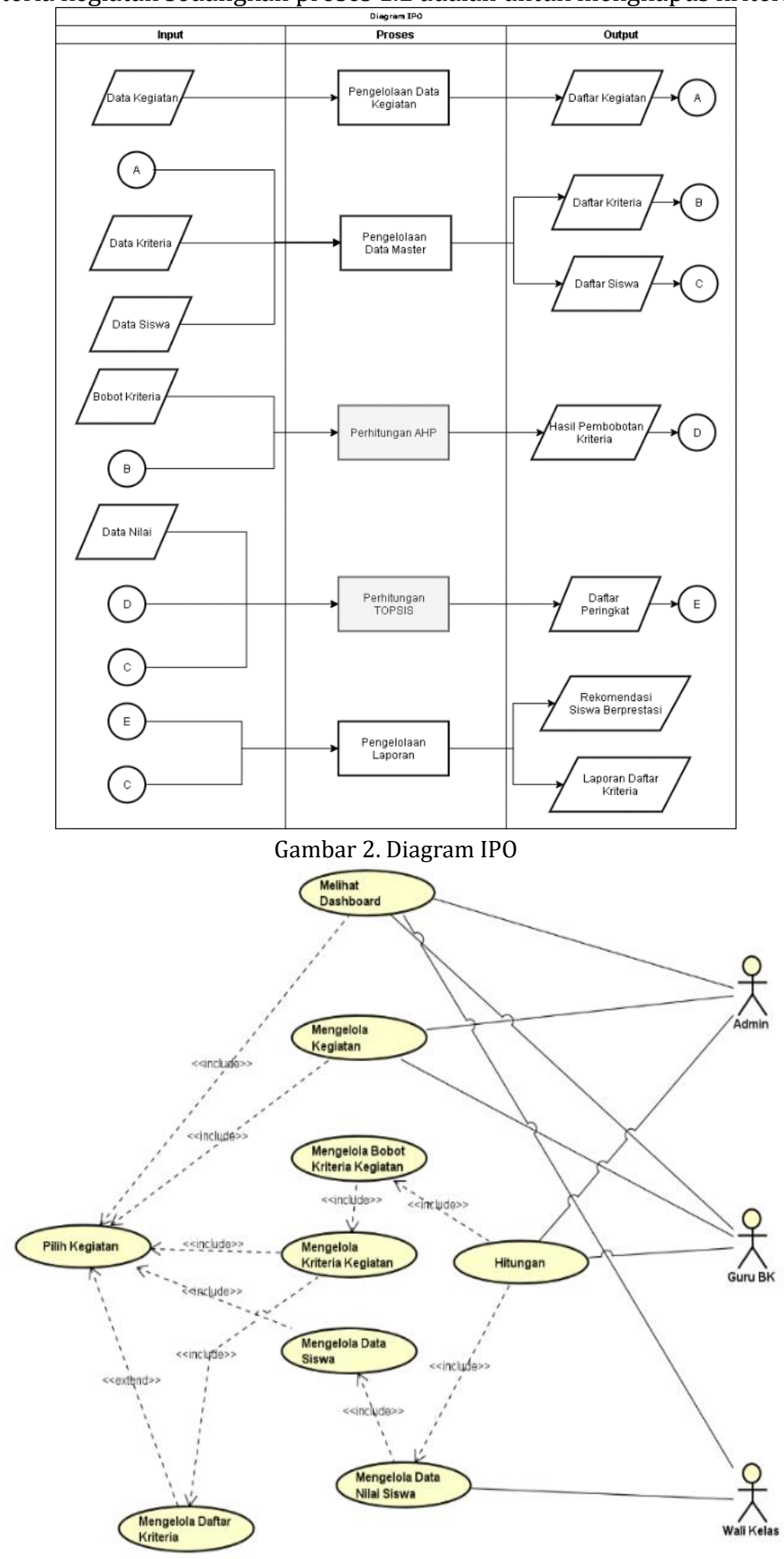

Gambar 3. Use Case Diagram

77 | Vol. 10 No. 2 /November 2021 http://doi.org/10.31504/komunika.v10i2.4488.

(c) 2021 Jurnal Komunika:Jurnal Komunikasi dan Informatika. Semua hak cipta dilindungi undang-undang. 


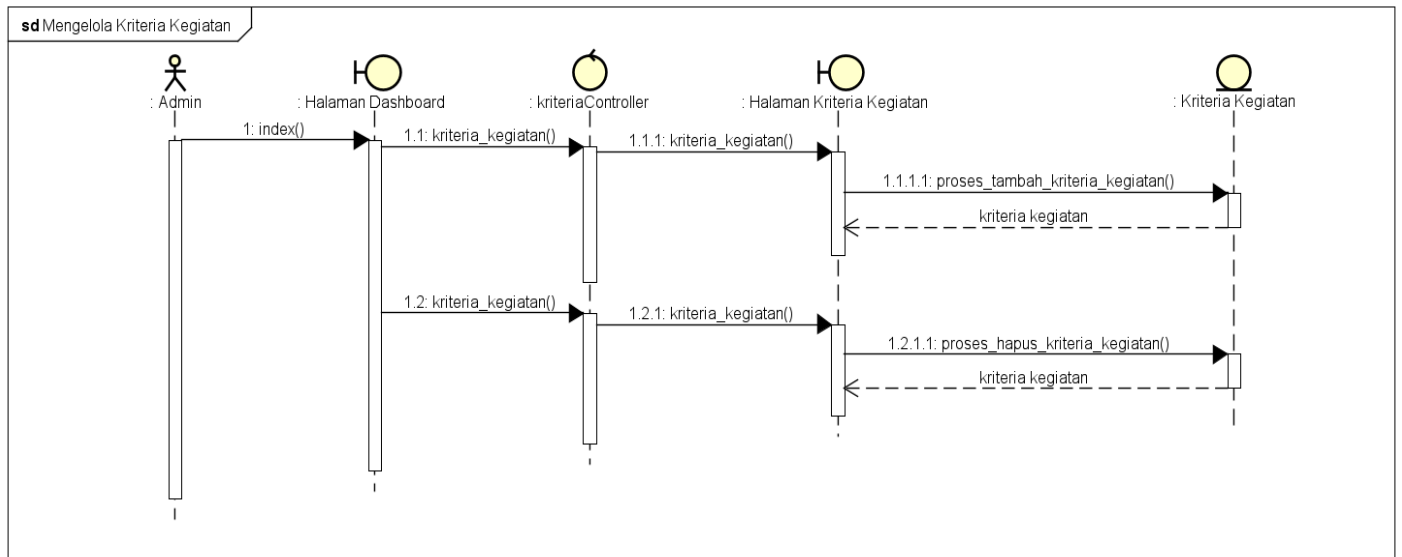

Gambar 4. Sequence Diagram Mengelola Kriteria Kegiatan

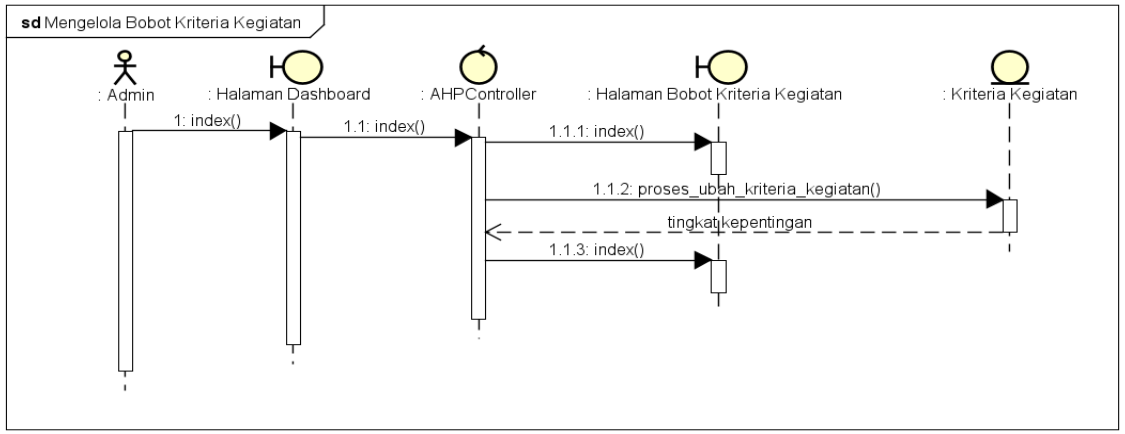

Gambar 5. Sequence Diagram Mengelola Bobot Kriteria Kegiatan

Pada Gambar 5 terlihat bahwa aktor berinteraksi dengan halaman dashboard serta halaman bobot kriteria kegiatan, aktor juga berinteraksi dengan controller AHP serta model kriteria kegiatan. Untuk sequence diagram ini digunakan untuk melakukan proses ubah bobot kriteria kegiatan.

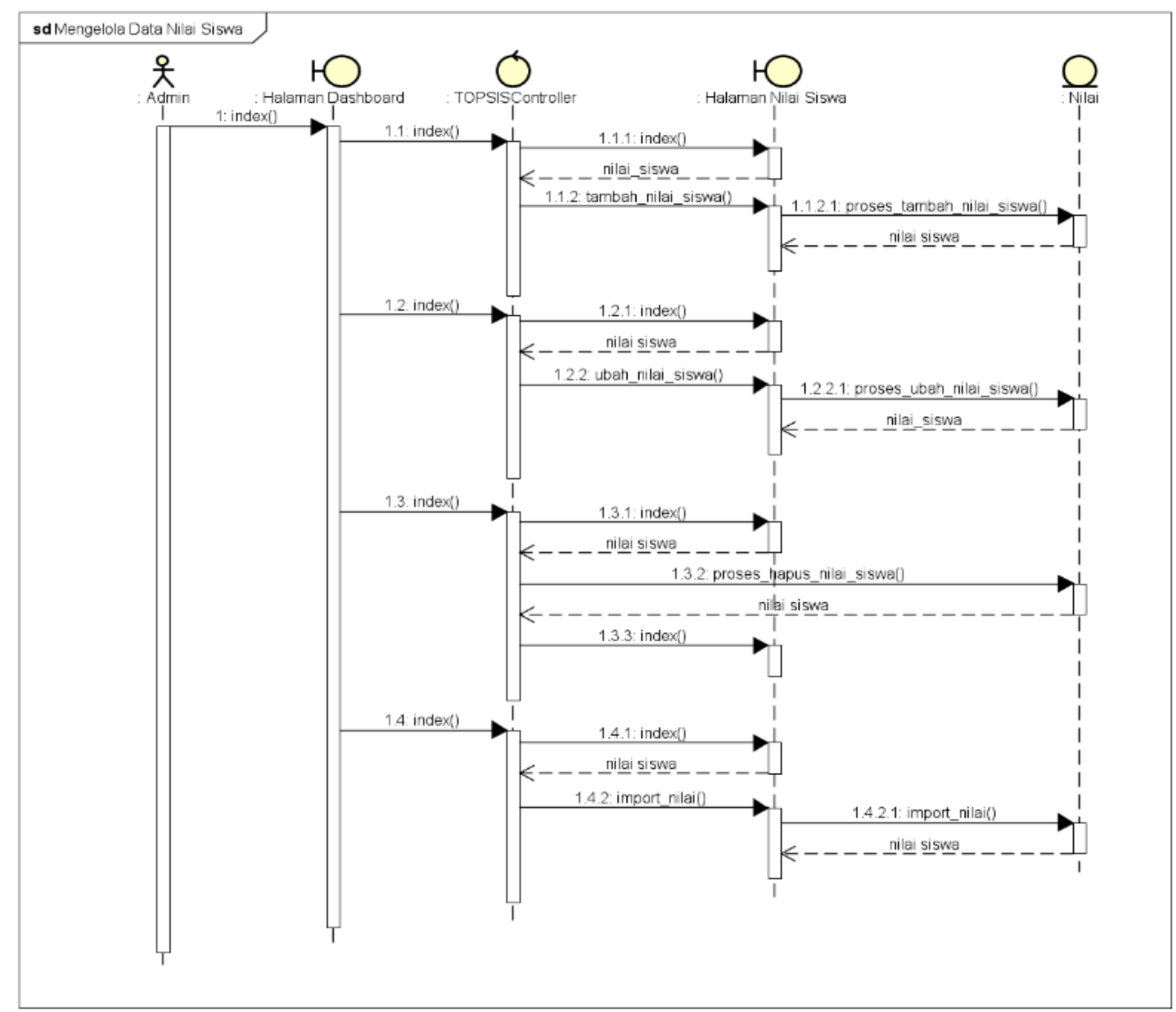

Gambar 6. Sequence Diagram Mengelola Data Nilai Siswa

78 | Vol. 10 No. 2 /November 2021 http://doi.org/10.31504/komunika.v10i2.4488.

(c) 2021 Jurnal Komunika:Jurnal Komunikasi dan Informatika. Semua hak cipta dilindungi undang-undang. 
Dari Gambar 6 di atas tergambar bahwa aktor berinteraksi dengan beberapa halaman yaitu halaman dashboard dan halaman nilai siswa, aktor juga berinteraksi dengan controller TOPSIS serta model nilai. 1.1 digunakan untuk melakukan tambah nilai siswa, 1.2 digunakan untuk melakukan ubah nilai siswa, 1.3 digunakan untuk melakukan hapus nilai siswa, sedangkan 1.4 digunakan untuk melakukan import nilai siswa.

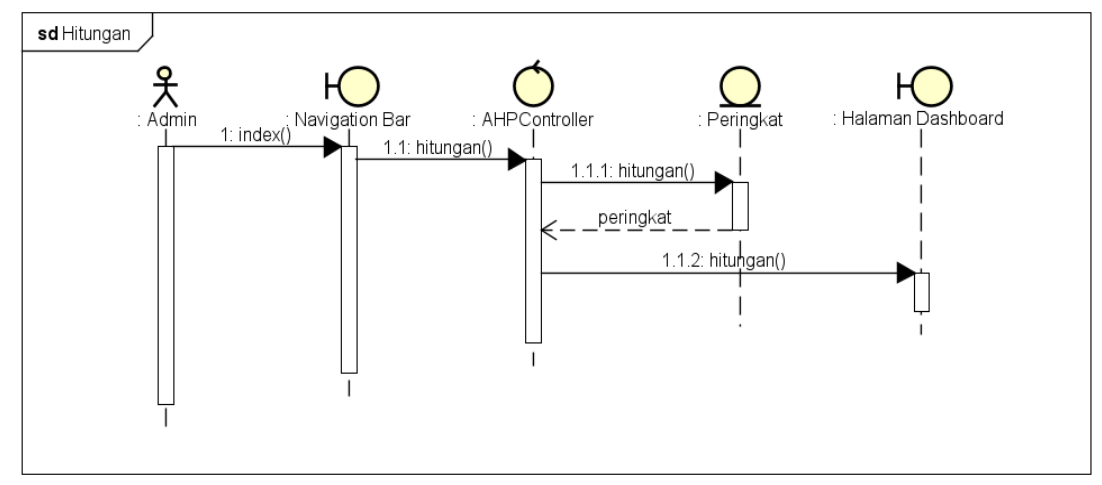

Gambar 7. Sequence Diagram Perhitungan

Berdasarkan Gambar 7, aktor berinteraksi dengan halaman dashboard, dengan controller AHP, dan model peringkat. Dalam proses ini termasuk didalamnya yaitu perhitungan yang melibatkan data nilai siswa serta bobot nilai kriteria kegiatan untuk ditampilkan dalam dashboard.

\section{Coding (Pengkodean)}

Tahap ini adalah model implementasi dari perancangan model sistem yang dibuat dalam bentuk kode program untuk dihasilkan perangkat lunak yang dimaksud. Dalam pembuatan aplikasi web untuk pemilihan siswa berprestasi ini menggunakan bahasa pemrograman PHP dengan HTML dibantu dengan Framework Laravel, CSS dan Javascript. Sedangkan untuk implementasi bais datanya menggunakan MariaDB (XAMPP).

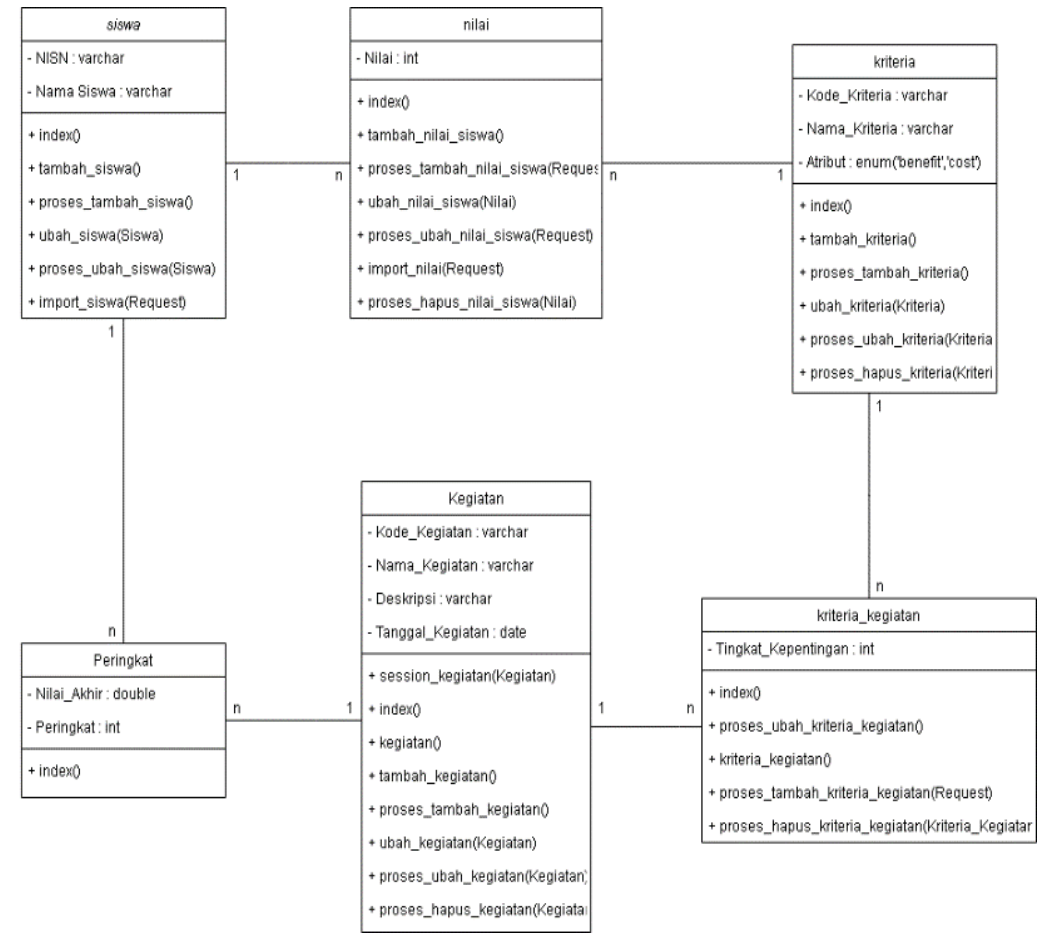

Gambar 8. Class Diagram

Class diagram pada Gambar 8 tersebut menggambarkan secara keseluruhan sistem beserta keseluruhan fungsi/proses yang berjalan didalamnya sehingga membentuk struktur yang diinginkan untuk proses perhitungan AHP-TOPSIS.

\section{Testing (Pengujian)}

Pada tahap ini, dilakukan pengujian sistem dengan menghitung keakuratan hasil luaran antara sistem dengan perhitungan manual dengan tambahan pengujian perangkat lunak menggunakan Black Box Testing. Black Box Testing yaitu pengujian yang dilakukan hanya mengamati hasil eksekusi melalui data uji dan memeriksa fungsional dari perangkat lunak (Astuti, 2018). Tahap ini dilakukan dengan melakukan uji awal program saat selesai pengkodean, lalu dilakukan evaluasi program, dilanjutkan dengan melakukan bug fix dan 
perbaikan lainnya, lalu dilakukan pengujian akhir dan pengembangan lebih lanjut. Untuk pengujian ini juga ditambahkan dengan uji keakurasian hasil yang ditampilkan oleh luaran aplikasi dan juga uji pembanding kecepatan sebelum dan sesudah penggunaan aplikasi. Tahap selanjutnya yaitu pengujian User Acceptance Testing (UAT) untuk dapat melihat hasil pengujian dan waktu uji coba yang dilakukan berdasarkan Use Case Diagram. UAT adalah suatu proses pengujian oleh pengguna yang dimaksudkan untuk menghasilkan dokumen yang dijadikan bukti bahwa software yang telah dikembangkan dapat diterima oleh pengguna (Wahyuningsih \& Wibawa, 2017).

\section{HASIL DAN PEMBAHASAN}

\section{Implementasi Perangkat Lunak SPK Pemilihan Siswa Berprestasi}

Sesuai dengan hasil perancangan yang telah dilakukan, pada tahap ini kita akan melakukan implementasi dalam bentuk aplikasi berbasis website dibantu dengan framework Laravel dengan database MySQL. Untuk pengguna (admin/guru BK) bisa menambahkan daftar kegiatan yang akan dilakukan seleksi, namun jika sebelumnya sudah ada kegiatan yang ada maka pengguna (wali kelas) bisa melakukan pengisian data lainnya. Gambar 9 menunjukkan tampilan untuk pengguna dapat melakukan pengelolaan data kriteria secara keseluruhan yang dapat digunakan dibanyak jenis kegiatan yang ada. Nantinya kriteria yang akan digunakan dalam pemeringkatan dalam kegiatan tertentu akan dapat diolah dalam daftar kriteria. Pada tahap ini, pengguna bebas menentukan jumlah kriteria yang digunakan dan tidak dibatasi penggunaannya (dinamis).

Pada Gambar 10 ini menunjukkan tampilan dimana pengguna dapat mengatur tingkat kepentingan pada masing-masing kriteria sesuai dengan tingkat kepentingan yang isinya disesuaikan dengan Gambar 9. Dari data yang sudah diisi secara manual ataupun melalui import excel, dilakukan pemilihan alternatif atau siswa sesuai dengan kebutuhan perhitungan. Data nilai ini bisa dilakukan import juga melalui excel dengan ketentuan dimana baris pertama pada excel isiannya harus ada semua sesuai pada Gambar 11. Tidak harus urut, melainkan harus ada.

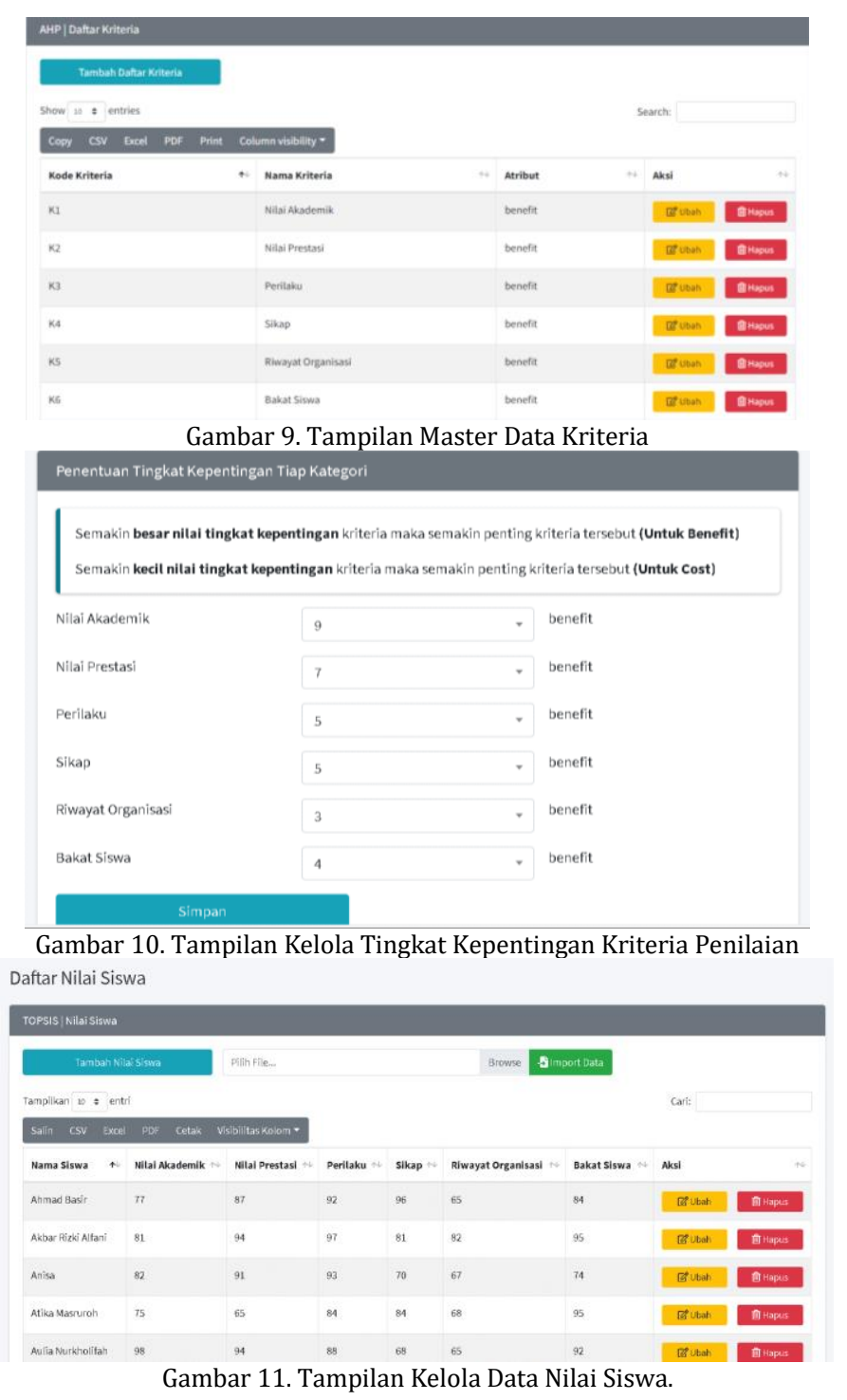

80 | Vol. 10 No. 2 /November 2021 http://doi.org/10.31504/komunika.v10i2.4488.

(c) 2021 Jurnal Komunika:Jurnal Komunikasi dan Informatika. Semua hak cipta dilindungi undang-undang. 


\section{Pengujian Perangkat Lunak SPK Pemilihan Siswa Berprestasi}

Pada tahap ini, semua fungsionalitas pada aplikasi yang tergambar dalam use case diagram diuji oleh tim peneliti dengan metode black-box. Hasil pengujian black-box menunjukkan semua fungsi yang ada pada aplikasi dapat berjalan dengan baik dan sukses. Untuk lengkapnya, hasil pengujian black-box dapat dilihat pada Tabel 3.

\begin{tabular}{|c|c|}
\hline Skenario Uji & Hasil yang Diharapkan dari Aplikasi \\
\hline $\begin{array}{l}\text { Pilih Kegiatan/Pilih } \\
\text { Menu }\end{array}$ & Aplikasi dapat menampilkan berbagai macam kegiatan/menu yang dipilih pengguna \\
\hline Dashboard & $\begin{array}{l}\text { Aplikasi dapat menampilkan kriteria, bobot kriteria, dan keterangan pendukung (sebelum } \\
\text { melakukan perhitungan). Jika pengguna sudah melakukan perhitungan, maka aplikasi dapat } \\
\text { menampilkan hasil akhir perhitungan AHP dan TOPSIS berupa rekomendasi siswa berprestasi. }\end{array}$ \\
\hline $\begin{array}{l}\text { Mengolah Daftar } \\
\text { Kriteria }\end{array}$ & $\begin{array}{l}\text { Aplikasi dapat mengolah daftar kriteria uji yang memungkinkan untuk dipilih ditiap masing-masing Berhasil } \\
\text { kegiatan yang ada }\end{array}$ \\
\hline Mengolah Kegiatan & $\begin{array}{l}\text { Aplikasi dapat mengolah berbagai macam kegiatan sehingga aplikasi dapat diimplementasikan untuk Berhasil } \\
\text { segala macam bentuk yang berhubungan dengan perhitungan untuk pengambilan keputusan }\end{array}$ \\
\hline $\begin{array}{l}\text { Mengolah Kriteria } \\
\text { Kegiatan }\end{array}$ & Aplikasi dapat mengolah data kriteria pada masing-masing kegiatan \\
\hline $\begin{array}{l}\text { Mengolah Bobot } \\
\text { Kriteria Kegiatan }\end{array}$ & Aplikasi dapat menentukan data bobot masing-masing kriteria yang didaftarkan pada suatu kegiatan Berhasil \\
\hline Mengolah Data Siswa & $\begin{array}{l}\text { Aplikasi dapat mengolah data siswa yang dimasukkan secara manual/unggah berupa file berekstensi Berhasil } \\
\text {.xlsx }\end{array}$ \\
\hline $\begin{array}{l}\text { Mengolah Data Nilai } \\
\text { Siswa }\end{array}$ & $\begin{array}{l}\text { Aplikasi dapat mengolah data nilai siswa yang dimasukkan secara manual/unggah berupa file } \\
\text { berekstensi .xlsx }\end{array}$ \\
\hline Perhitungan & $\begin{array}{l}\text { Aplikasi dapat melakukan perhitungan AHP dan TOPSIS dan menghasilkan rekomendasi atau } \\
\text { peringkat siswa berprestasi }\end{array}$ \\
\hline
\end{tabular}

Selain black-box testing, pengujian setiap fungsi dari aplikasi juga dilakukan kepada pengguna akhir dengan menggunakan metode UAT. Hal ini bertujuan untuk mengukur tingkat penerimaan aplikasi oleh pengguna dan hasil pengujian UAT secara lengkap tertuang pada tabel 4. Tabel tersebut menunjukkan bahwa semua fungsi dari aplikasi dapat diterima dengan baik oleh pengguna akhir. Waktu yang dibutuhkan oleh pengguna dalam menjalankan aplikasi pun relatif cepat.

Tabel 4. Hasil Pengujian UAT

\begin{tabular}{|c|c|c|c|}
\hline Skenario Uji & Hasil yang Diharapkan dari Pengguna & Kesimpulan & Durasi \\
\hline $\begin{array}{l}\text { Pilih Kegiatan/Pilih } \\
\text { Menu }\end{array}$ & Pengguna dapat memilih berbagai macam kegiatan/menu yang disediakan & Diterima & $<1$ Menit \\
\hline Cek Dashboard & $\begin{array}{l}\text { Pengguna dapat melihat kriteria, bobot kriteria, dan keterangan pendukung (sebelum } \\
\text { melakukan perhitungan). Jika pengguna sudah melakukan perhitungan, maka pengguna } \\
\text { akan disuguhkan oleh hasil perhitungan. }\end{array}$ & Diterima & $<1$ Menit \\
\hline $\begin{array}{l}\text { Mengolah Daftar } \\
\text { Kriteria }\end{array}$ & $\begin{array}{l}\text { Pengguna dapat mengolah daftar kriteria uji yang memungkinkan untuk dipilih ditiap } \\
\text { masing-masing kegiatan yang ada }\end{array}$ & Diterima & 1-2 Menit \\
\hline Mengolah Kegiatan & $\begin{array}{l}\text { Pengguna dapat mengolah berbagai macam kegiatan sehingga aplikasi dapat } \\
\text { diimplementasikan untuk segala macam bentuk yang berhubungan dengan perhitungan } \\
\text { untuk pengambilan keputusan }\end{array}$ & Diterima & 1-2 Menit \\
\hline $\begin{array}{l}\text { Mengolah Kriteria } \\
\text { Kegiatan }\end{array}$ & Pengguna dapat mengolah kriteria pada masing-masing kegiatan & Diterima & 1-2 Menit \\
\hline $\begin{array}{l}\text { Mengolah Bobot } \\
\text { Kriteria Kegiatan }\end{array}$ & $\begin{array}{l}\text { Pengguna dapat menentukan bobot masing-masing kriteria yang didaftarkan pada suatu } \\
\text { kegiatan }\end{array}$ & Diterima & 1-3 Menit \\
\hline Mengolah Data Siswa & $\begin{array}{l}\text { Pengguna dapat mengolah data siswa secara manual/melakukan upload menggunakan file } \\
\text { berekstensi .xlsx }\end{array}$ & & 1-3 Menit \\
\hline $\begin{array}{l}\text { Mengolah Data Nilai } \\
\text { Siswa }\end{array}$ & $\begin{array}{l}\text { Pengguna dapat mengolah data nilai siswa secara manual/melakukan upload } \\
\text { menggunakan file berekstensi .xlsx }\end{array}$ & Diterima & 1-3 Menit \\
\hline Perhitungan & $\begin{array}{l}\text { Pengguna dapat meminta aplikasi untuk melakukan perhitungan AHP dan TOPSIS dan } \\
\text { menunggu hasil rekomendasi siswa berprestasi }\end{array}$ & Diterima & 1-3 Menit \\
\hline
\end{tabular}

Pengujian selanjutnya untuk mengecek apakah berjalannya perhitungan sudah sesuai antara perhitungan AHP-TOPSIS melalui aplikasi dan perhitungan manual. Contoh studi kasus yang diberikan menggunakan 6 kriteria dan 104 alternatif/siswa. Hasil perhitungan AHP dan TOPSIS pada aplikasi untuk studi kasus yang ada dapat dilihat pada Gambar 12.

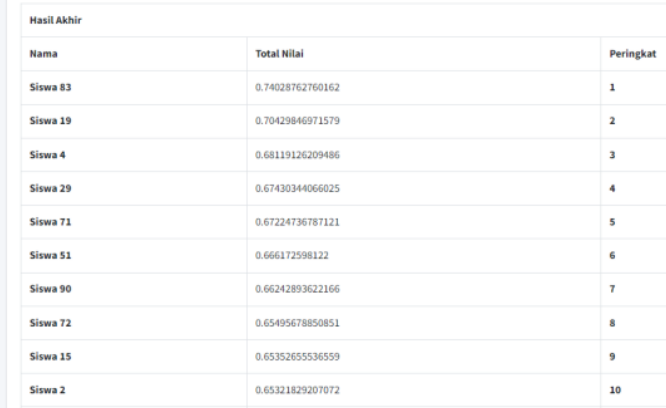

Gambar 12. Tampilan Debug Perhitungan AHP-TOPSIS - Perhitungan Akhir. 
Antara tiap nilai pembanding yang ada pada alternatif akan menjadi kunci tiap nilai akhir ini. Nantinya tiap masing-masing nilai akhir ini akan diurutkan dari nilai terbesar ke yang terkecil untuk pemeringkatannya. Dari keseluruhan proses ditemukan bahwa alternatif bernama Siswa 83 mendapat poin 0.74029 dengan prosedur perhitungan AHP-TOPSIS. Hasilnya ditampilkan pada tampilan menu utama pada aplikasi ini, seperti Gambar 13.

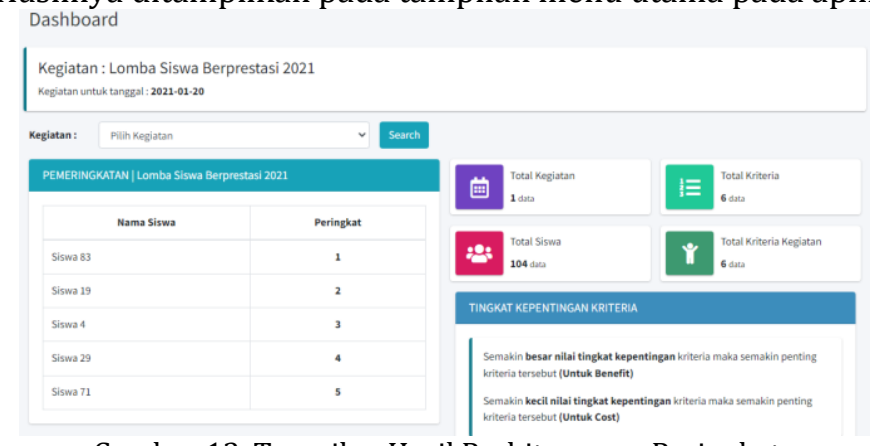

Gambar 13. Tampilan Hasil Perhitungan - Peringkat.

Secara keseluruhan proses, mulai dari input semua data yang dibutuhkan hingga aplikasi menampilkan rekomendasi siswa berprestasi hanya diperlukan waktu kurang dari 20 menit. Dengan demikian, aplikasi dapat mempersingkat waktu seleksi dengan hasil luaran yang optimal. Untuk pengujian akurasi dilakukan sesuai dengan rumus perhitungan yang ada dengan perhitungan manual menggunakan Microsoft Excel. Dalam uji ini menggunakan 104 data alternatif siswa dengan 6 macam kriteria pembobotan. Hasil perhitungan manual ini sama persis dengan hasil rekomendasi pada aplikasi SPK. Adapun hasil perhitungan manual dapat dilihat di Tabel 5.

Tabel 5. Hasil Perhitungan Manual Menggunakan Excel

\begin{tabular}{|c|c|c|}
\hline Nama Siswa & Nilai Akhir & Peringkat \\
\hline Siswa 83 & 0,74029 & 1 \\
\hline Siswa 19 & 0,70430 & 2 \\
\hline Siswa 4 & 0,68119 & 3 \\
\hline Siswa 29 & 0,67430 & 4 \\
\hline Siswa 71 & 0,67225 & 5 \\
\hline Siswa 51 & 0,66617 & 6 \\
\hline Siswa 90 & 0,66243 & 7 \\
\hline Siswa 72 & 0,65496 & 8 \\
\hline Siswa 15 & 0,65353 & 9 \\
\hline Siswa 2 & 0,65322 & 10 \\
\hline Siswa 6 & 0,64136 & 11 \\
\hline Siswa 96 & 0,62837 & 12 \\
\hline Siswa 27 & 0,62697 & 13 \\
\hline Siswa 44 & 0,62006 & 14 \\
\hline Siswa 97 & 0,61558 & 15 \\
\hline
\end{tabular}

Setelah itu kita bandingkan hasilnya dengan hasil luaran yang ada dalam sistem. Diperoleh bahwa dari 104 data alternatif yang ada, didapatkan 0 data yang tidak sesuai. Dengan demikian, tingkat akurasi dapat dihitung dengan rumus 1 (Aqli, dkk., 2016):

$$
\text { Akurasi }=\frac{\left(\sum n-\varepsilon\right)}{\sum n} x 100 \%
$$

Keterangan:

$\mathrm{n}=$ jumlah data; $\mathrm{e}=$ jumlah perbedaan

$$
\text { Akurasi }=\frac{(104-0)}{104} x 100 \%=100 \%
$$

Berdasarkan hasil tersebut, keakuratan aplikasi ini dengan metode perhitungan AHP-TOPSIS manual menggunakan Microsoft Excel bisa dibilang sempurna. Dengan ini perhitungan didalam sistem bisa dipertanggungjawabkan keakuratannya.

\section{KESIMPULAN}

Penerapan Sistem Pendukung Keputusan (SPK) penentuan siswa berprestasi menggunakan metode AHP dan TOPSIS ini terbukti dapat membantu mempercepat waktu seleksi siswa berprestasi yang akan dikirim ke suatu kompetisi, yang semula 1-2 minggu menjadi kurang dari 20 menit. Tingkat akurasi dari perhitungan AHP dan TOPSIS yang dihasilkan aplikasi juga mencapai 100\%. Selain itu, segala bentuk proses input data dengan jumlah yang cukup besar dapat terbantu dengan fitur import sehingga dapat memangkas waktu cukup signifikan. Dari aplikasi yang dibuat, dilakukan uji coba menggunakan metode black-box dan UAT. Hasil pengujian menunjukkan semua fungsi yang ada pada aplikasi dapat berjalan dengan sukses dan diterima dengan baik oleh pengguna. 


\section{DAFTAR PUSTAKA}

Aqli, I., Ratnawati, D. E., \& Data, M. (2016). Sistem Rekomendasi Pemilihan Sekolah Menengah Atas Sederajat Kota Malang Menggunakan Metode AHP ELECTRE Dan TOPSIS. Jurnal Teknologi Informasi Dan Ilmu Komputer, 3(4), 279. https://doi.org/10.25126/jtiik.201634228

Astuti, P. (2018). Penggunaan Metode Black Box Testing (Boundary Value Analysis) Pada Sistem Akademik (Sma/Smk). Faktor Exacta, 11(2), 186. https://doi.org/10.30998/faktorexacta.v11i2.2510

Azis, G. M. al, Cholissodin, I., \& Furqon, M. T. (2017). Sistem Pendukung Keputusan untuk Rekomendasi Wirausaha Menggunakan Metode AHP-TOPSIS (Studi Kasus Kab. Probolinggo). Jurnal Pengembangan Teknologi Informasi Dan Ilmu Komputer, 1(11), 1204-1214. https://j-ptiik.ub.ac.id/index.php/j-ptiik/article/view/435

Carolina, I., \& Supriyatna, A. (2019). Penerapan Metode Extreme Programming Dalam Perancangan Aplikasi Perhitungan Kuota SKS Mengajar Dosen. Jurnal IKRA-ITH Informatika, 106-113. https://journals.upiyai.ac.id/index.php/ikraith-informatika/article/view/306

Chamid, A. A. (2016). Penerapan Metode TOPSIS Untuk Menentukan Prioritas Kondisi Rumah. Jurnal Simetris, 7(2), 537-533. https://doi.org/https://doi.org/10.24176/simet.v7i2.765

Chamid, A. A., \& Murti, A. C. (2017). Kombinasi Metode AHP dan TOPSIS Pada Sistem Pendukung Keputusan. Prosiding SNATIF, 115-119.

Ekayani, N. L. P. (2017). Pentingnya Penggunaan Media Pembelajarana Untuk Meningkatkan Prestasi Belajar Siswa. Jurnal Fakultas Ilmu Pendidikan Universitas Pendidikan Ganesha. https://www.researchgate.net/publication/315105651_PENTINGNYA_PENGGUNAAN_MEDIA_PEMBELAJARAN_ UNTUK_MENINGKATKAN_PRESTASI_BELAJAR_SISWA

Fadlan, M., Muhammad, \& Hadriansa. (2017). Terapan Kombinasi Metode TOPSIS dan Analitycal Hierarchy Process Pada Rekomendasian Penerima Beasiswa Peningkatan Prestasi Akademik (Studi Kasus Pada STMIK PPKIA Tarakanita Rahmawati). Jurnal Simetris, 663-670. https://doi.org/https://doi.org/10.24176/simet.v8i2.1565

Jodi, K. I. (2017). Penentuan Siswa Berprestasi Menggunakan Metode K-Nearest Neighbor dan Weighted Product (Studi Kasus : SMP Negeri 3 Mejayan). Jurnal Pengembangan Teknologi Informasi Dan Ilmu Komputer, 1(5), 352360. https://j-ptiik.ub.ac.id/index.php/j-ptiik/article/view/105

Lemantara, J., \& Utama, I. G. (2009). Rancang Bangun Sistem Pengolahan Administrasi Berbasis Web pada Kemahasiswaan STIKOM Surabaya. Seminar Nasional Sistem \& Teknologi Informasi (SNASTI) (pp. 191-201). Surabaya: STIKOM.

Lemantara, J., Setiawan, N. A., \& Aji, M. N. (2013). Sistem Pendukung Keputusan Pengoptimalan Pembagian Tugas dengan Kombinasi Metode Hungarian dan Permutasi. JNTETI, 20-28.

Lesmana, A. Y., \& Nugroho, A. C. (2021). Penggunaan Metode TOPSIS untuk Sistem Pendukung Keputusan Pemilihan Siswa Berprestasi di MAN 1 Metro. Teknologi Terkini, 1-16.

Marbun, M., \& Sinaga, B. (2018). Buku Ajar Sistem Pendukung Keputusan Penilaian Hasil Belajar dengan Metode TOPSIS (N. Siahaan \& T. F. Manurung, Eds.). CV Rudang Mayang.

Mulyoningtyas, A., Satyareni, D. H., \& Masrur, M. (2016). Perancangan Sistem Pendukung Keputusan untuk Menentukan Siswa Berprestasi Menggunakan Metode Ahp (Analytical Hierarchy Process) Berbasis Java. Nusantara of Enginering, 3(1), 21-28. https://ojs.unpkediri.ac.id/index.php/noe/article/view/243

Munthafa, A. E., \& Mubarok, H. (2017). Penerapan Metode Analytical Hierarchy Process Dalam Sistem Pendukung Keputusan Penentuan Mahasiswa Berprestasi. Jurnal Siliwangi, 3(2), 192-201. http://jurnal.unsil.ac.id/index.php/jssainstek/article/view/355

Nyura, Y., A, A. R. D., \& Elizabeth, E. (2020). Pemilihan Siswa Berprestasi Menggunakan Metode AHP TOPSIS. Seminnar Nasional Penelitian \& Pengabdian Kepada Masyarakat 2020, 135-140.

Pangaribuan, L. J., Sylvia, T., \& Hutabarat, L. T. (2021). Analisis Metode Analytic Hierarchy Process Dalam Sistem Pendukung Keputusan Pemilihan Taruna Berprestasi. Jurnal Media Informatika Budidarma, 344-351.

Rahman, A. L., Hasbi, M., \& Setiyowati. (2020). Sistem Pendukung Keputusan Untuk Pemilihan Siswa Berprestasi Dengan Metode Analytical Hierarchy Process (AHP) Dan Technique For Order Of Preference By Similarity To Ideal Solution (TOPSIS). Jurnal Ilmiah SINUS, https://doi.org/http://dx.doi.org/10.30646/sinus.v18i1.439

Setiadi, H. (2016). Pelaksanaan Penilaian Pada Kurikulum 2013. Jurnal Penelitian Dan Evaluasi Pendidikan, $166-178$. https://doi.org/10.21831/pep.v20i2.7173

Supriyatna, A. (2018). Metode Extreme Programming Pada Pembangunan Web Aplikasi Seleksi Peserta Pelatihan Kerja. Jurnal Teknik Informatika, 11(1), 1-18. https://doi.org/10.15408/jti.v11i1.6628

Tristianto, C. (2018). Penggunaan Metode Waterfall Untuk Pengembangan Sistem Monitoring dan Evaluasi Pembangunan Pedesaan. Jurnal Teknologi Informasi, 12(1), 8-22.

Utama, D. N. (2017). Sistem Penunjang Keputusan: Filosofi, Teori, dan Implementasi. Penerbit Garudhawaca.

Wahyuningsih, Y., \& Wibawa, S. C. (2017). Pengembangan Aplikasi Test Online Dengan Menggunakan Framework CodeIgniter di SMK Darul Ma'wa Plumpang pada Mata Pelajaran Jaringan Dasar Kelas X. IT-Edu: Jurnal Information Technology and Education, 2(2), 36-46. https://ejournal.unesa.ac.id/index.php/itedu/article/view/22139 